\title{
Gelombang Pengungsi Korea Utara di Korea Selatan: Politik Domestik, Integrasi, dan Permasalahan Sosial
}

\author{
Vinesha Anindita \\ Universitas Airlangga
}

\begin{abstract}
ABSTRAK
Tulisan ini membahas mengenai gelombang pengungsi Korea Utara di Korea Selatan serta bagaimana permasalahan-permasalahan muncul pada tingkat politik domestik hingga tingkat sosial masyarakat. Gelombang pengungsi telah terjadi sejak pemisahan kedua Korea melalui garis paralel ke-38, yang memunculkan pembelotan dari Korea Utara. Sementara itu, Korea Selatan dianggap sebagai tempat yang ideal dan aman untuk berlindung. Hal ini kemudian menimbulkan permasalahan yang dapat dijelaskan dengan setidaknya dua kerangka pemikiran, yaitu world system theory dalam menjelaskan keinginan untuk bermigrasi, dan paradoks multikulturalisme yang menjelaskan timbulnya gesekan-gesekan sosial dan kebudayaan. Diskursus identitas serta permasalahan sosial menjadi tantangan tersendiri bagi pemerintah Korea Selatan. Pada satu sisi, pengungsi Korea Utara dapat memberikan informasi yang menguntungkan bagi pemerintah. Pada sisi lain, terdapat dua permasalahan sosial yang muncul, yaitu permasalahan jangka panjang bagi pengungsi dalam bertahan dari beban mental dan finansial, serta stigma negatif dan xenofobia masyarakat Korea Selatan terhadap pengungsi. Hal-hal tersebut yang kemudian menjadi alasan mengapa integrasi sulit dilakukan terhadap pengungsi.
\end{abstract}

Kata-kata Kunci: Pengungsi, World System Theory, Multikulturalisme, Identitas

This research attempts to analyze the wave of North Korean refugees to South Korea and how problems arise on the domestic political level to the societal level. Waves of refugees have occurred since the division of the two Koreas through the 38 parallel, which gave rise to defections from North Korea. Meanwhile, South Korea is perceived as an ideal and safe place to take shelter. This in turn raised numerous problems explicable by at least two theoretical frameworks, namely the world system theory in explaining the desire to migrate, and the multiculturalist paradox, which explains the emergence of social and cultural frictions. Discourse on identity and social problems poses a challenge for the South Korean government. On one hand, North Korean refugees can provide beneficial information for the government. On the other hand, two social problems arise, namely the long-term problem for refugees in surviving the mental and financial burdens, as well as the negative stigma and xenophobia placed by the South Korean society on the refugees. These are the reasons why integration remains difficult for refugees.

Keywords: Refugees, World System Theory, Multiculturalism, Identity 
Sejak Perang Korea dan pembagian wilayah melalui garis paralel ke-38 pada tahun 1953, masyarakat terpaksa tinggal sesuai wilayah yang ditinggali. Banyak dari mereka terpisah secara paksa dari kerabat dan keluarga di kampung halaman dan tidak dapat kembali. Korea Utara di bawah sistem komunis dengan pemerintahan yang otoriter dianggap melanggar hak asasi manusia masyarakat dengan melakukan berbagai pembatasan ruang gerak dan hukuman yang tidak manusiawi. Selain itu, Korea Utara juga menghadapi permasalahan kelaparan. Maka dari itu, banyak warga Korea Utara melarikan diri dan mencari suaka di Korea Selatan. Dari sudut pandang Korea Utara, pengungsi-pengungsi (saeteomin) ini merupakan pembelot yang harus dihukum dengan berat, bahkan mendapat hukuman mati.

Penerimaan pengungsi Korea Utara oleh Korea Selatan dilakukan untuk pertama kalinya pada masa pemerintahan Park Chung Hee pada tahun 1962. Kebijakan untuk menerima pengungsi ini selanjutnya diinstitusionalisasikan secara legal ke dalam hukum Korea Selatan. Pada era Park Chung Hee, secara hukum status pengungsi setelah memasuki wilayah Selatan diatur dalam Special Law on the Protection of Defectors from the North (Lankov 2006). Meskipun mereka melarikan diri dari lingkungan yang represif secara politik dan ekonomi, pengungsi Korea Utara yang kemudian tinggal di Korea Selatan tidak lantas dibebaskan dari tantangan tambahan setelah mereka menetap. Para pengungsi ini, semisal, mengalami kondisi kesehatan mental yang buruk. Post traumatic syndrome disorder (PTSD) menjadi perhatian khusus yang kerap melekat pada pengungsi yang berhasil menyeberang dikarenakan oleh kekerasan yang dilihat maupun dirasakan ketika masih berada di Korea Utara maupun pada saat proses penyeberangan.

Sejak tahun 1998 hingga 2011 terjadi peningkatan jumlah penyeberang yang cukup signifikan, yaitu hampir 3 kali jumlah tahun 1998 pada tahun 2011. Meskipun sejak tahun 2012 angka penyeberang dari Korea Utara mengalami penurunan signifikan, ketika dijumlahkan hingga tahun 2019, angka yang dihasilkan masih terhitung tinggi. Setidaknya 1047 penyebrang yang baru datang di Korea Selatan pada tahun 2019 menambah akumulasi pengungsi beserta permasalahan-permasalahan baru yang dibawanya. Permasalahan selanjutnya adalah permasalahan perbatasan antara kedua negara, karena terkadang isu-isu pengungsi dapat menjadi sensitif dan memicu memanasnya kembali konflik di Semenanjung Korea. Satu hal yang kemudian menjadi pertanyaan besar adalah 
mengapa pengungsi memilih Korea Selatan, ketika Cina seharusnya juga berpotensi menjadi negara destinasi apabila dilihat dari sisi geografis.

\section{Tabel 1. Jumlah Pengungsi Korea Utara ke Korea Selatan Setiap Tahun}

\begin{tabular}{|c|c|c|c|c|c|}
\hline Tahun & $\mathbf{1 9 9 8}$ & $\mathbf{2 0 0 1}$ & $\mathbf{2 0 0 2}$ & $\mathbf{2 0 0 3}$ & $\mathbf{2 0 0 4}$ \\
\hline Angka & 947 & 1043 & 1142 & 1285 & 1898 \\
\hline Tahun & $\mathbf{2 0 0 5}$ & $\mathbf{2 0 0 6}$ & $\mathbf{2 0 0 7}$ & $\mathbf{2 0 0 8}$ & $\mathbf{2 0 0 9}$ \\
\hline Angka & 1384 & 2028 & 2554 & 2803 & 2914 \\
\hline Tahun & $\mathbf{2 0 1 0}$ & $\mathbf{2 0 1 1}$ & $\mathbf{2 0 1 2}$ & $\mathbf{2 0 1 3}$ & $\mathbf{2 0 1 4}$ \\
\hline Angka & 2402 & 2706 & 1502 & 1514 & 1397 \\
\hline Tahun & $\mathbf{2 0 1 5}$ & $\mathbf{2 0 1 6}$ & $\mathbf{2 0 1 7}$ & $\mathbf{2 0 1 8}$ & $\mathbf{2 0 1 9}$ \\
\hline Angka & 1275 & 1418 & 1127 & 1137 & 1047 \\
\hline
\end{tabular}

Sumber: Ministry of Unification 2019.

Tidak hanya pada tingkat negara, terdapat juga permasalahanpermasalahan sosial dalam interaksi antara pengungsi dengan penduduk lokal Korea Selatan. Integrasi menjadi sulit karena terdapat sedikit perbedaan budaya, dialek, kebiasaan hidup, serta diskriminasi terhadap pengungsi dari Korea Utara. Para pengungsi ini pergi ke Korea Selatan dengan harapan yang tinggi, tetapi seringkali harapan itu tidak tercapai dikarenakan kurangnya pemahaman para pengungsi tentang masyarakat dan budaya Korea Selatan. Hal ini kemudian memicu permasalahan-permasalahan sosial lainnya, seperti sulitnya mendapat pekerjaan bagi pengungsi Korea Utara dan tendensi pengungsi-pengungsi tersebut untuk terlibat dalam tindakan-tindakan kriminal. Penulis dengan demikian berargumentasi bahwa kebijakan pemerintah Korea Selatan untuk menerima secara terbuka pengungsi dari Korea Utara tidak sejalan dengan tantangan yang dihadapi pengungsi ketika hidup secara langsung dalam masyarakat Korea Selatan yang memiliki perbedaan identitas, sehingga menjadi lebih sulit bagi pengungsi-pengungsi tersebut untuk mengintegrasikan diri ke dalam masyarakat Korea Selatan. 


\section{Pendekatan Konseptual dan Definisi Pengungsi}

Penulis menggunakan dua pendekatan konseptual. Pendekatan yang pertama adalah world system theory. Teori ini memandang bahwa migrasi merupakan sebuah perkembangan alami dari gangguan dan dislokasi yang pasti terjadi dalam proses perkembangan kapitalis. Teori ini memproposisikan bahwa hubungan negara-negara dengan ekonomi kapitalis dengan negara berkembang, khususnya negaranegara non-kapitalis, pada kelanjutannya akan menciptakan mobilisasi masyarakat dari negara berkembang atau non-kapitalis ke negara-negara ekonomi kapitalis. Sebagai anggota dari G20, pada tahun 2010 Korea Selatan memberikan pengaruh besar terhadap proses dari G2O dan memainkan peranan penting dalam keberhasilan mobilisasi East Asian Caucus. Dalam G20, Korea Selatan memiliki komitmen untuk menolak segala bentuk proteksionisme dalam kebijakan-kebijakan perdagangan. Sebagai konsekuensi dari ini, negara-negara Asia lain harus memberikan dukungan terhadap kepemimpinan Korea Selatan dalam upaya internasional untuk menjaga pasar domestik yang terbuka melewati resesi. Dampak dari ini adalah keberhasilan negara-negara Asia dalam memeroleh peranan yang lebih besar dalam ekonomi global. Kemajuan dan kebebasan ekonomi di Korea Selatan inilah yang kemudian dapat menjadi faktor penarik bagi migran maupun pengungsi. Kontras dapat dilihat pada implementasi dari Juche, adalah ideologi negara Korea Utara yang sering diterjemahkan sebagai "autarki" atau "kemandirian". Inti ideologi ini, yang dikembangkan selama dekade 1970-an, adalah penempatan kepentingan dan karakteristik nasional pada prioritas puncak (Eschborn 2014).

Pendekatan konseptual kedua yang digunakan dalam penelitian ini adalah multikulturalisme. Multikulturalisme dicirikan sebagai perayaan keragaman etnokultural yang menyenangkan, mendorong warga untuk mengakui dan merangkul beragam persenjataan tradisional, tradisi, musik, dan masakan yang ada dalam masyarakat multietnis (Kymlicka 2012). Sedangkan Watson (2010) mendefinisikan multikulturalisme sebagai banyaknya pelaku budaya yang berbeda yang berjuang untuk melindungi dan membentuk identitas dalam ruang politik yang lebih luas. Watson (2012) melanjutkan bahwa multikulturalisme di Asia umumnya ditandai oleh tiga kelompok: (1) kelompok pribumi atau sub-nasional; (2) imigran baru atau migran ekonomi; dan (3) kelompok yang dikenal sebagai "metics" (pencari suaka / pengungsi yang menunggu status hukum), atau penduduk yang secara teknis merupakan warga negara 
Korea Selatan tetapi masih dikecualikan dari lembaga-lembaga politik dan budaya.

"The increase in immigrants is changing Korea into the multicultural society. Some see the multiculturalism as a trend whereas others see it as a value that we must support. Some Koreans reject multiculturalism because of their homogeneous tradition while others are working to transition in the culture and lifestyle of a multicultural society." (Watson 2012)

Peningkatan pesat jumlah pekerja migran dan perkawinan internasional mempromosikan gagasan multikulturalisme di Korea Selatan (Ahn 2013). Satu hal yang menarik dari paradoks multikultural di Korea Selatan adalah fakta bahwa masyarakat Korea Selatan bersifat multikultural namun pada saat yang sama tidak menjalankan multikulturalisme. Hal ini disebabkan oleh sejarah panjang penjajahan oleh asing, seperti Jepang dan campur tangan Amerika Serikat saat Perang Korea, yang menyebabkan berkembangnya xenophobia dalam masyarakat. Wacana umum tentang 'ras' atau 'etnisitas' di Korea Selatan adalah bahwa heterogenitas Korea menjadi risiko berkembangnya 'nasionalisme darah-murni' (Han 2012). Pada dasarnya, yang menjadi latar belakang diskriminasi ataupun rasisme masyarakat Korea Selatan adalah kepercayaan mereka terhadap superioritas kebudayaan Korea (Koo 2007 dalam Watson 2012). Superioritas atas darah murni Korea Selatan menjadi dasar bagi diskriminasi terhadap warga negara asing, migran, bahkan juga warga Korea Selatan yang berdarah campuran. Watson (2012) berargumen bahwa model dari multikulturalisme di Korea Selatan merupakan "stateled multiculturalism". Multikulturalisme jenis ini ini berakar pada agenda pemerintah untuk menunjukkan toleransi lebih terhadap perbedaan etnis, ras, kebudayaan, serta kewarganegaraan. Kebijakan multikulturalisme dianggap menentukan kekuatan ekonomi, keamanan, dan budaya nasional Korea Selatan saat ini dan di masa depan (Watson 2010).

Pemberian status pengungsi ditentukan oleh negara, berbeda dengan pencari suaka. Status pengungsi diberikan kepada individu, bukan kelompok. Sebagai akibatnya, penerimaan individu terpilih sebagai pengungsi dan penyediaan perlindungan kepada individuindividu tersebut diundangkan dalam hukum domestik dan didasarkan pada kedaulatan nasional negara itu sendiri (Choi 2018). Permasalahan pengungsi sering kali muncul karena berbagai motif, khususnya motif politik oleh negara. Pada tahun 1950, Perserikatan 
Bangsa-Bangsa (PBB) mendefinisikan pengungsi sebagai seseorang yang memperlihatkan ketakutan akan penganiayaan yang didasari oleh alasan ras, agama, kebangsaan, keanggotaan kelompok sosial, atau opini politik tertentu yang berada di luar negara dari status kenegaraannya, dan tidak dapat atau-dikarenakan ketakutan tersebut-tidak memiliki keinginan untuk kembali ke negara asalnya (Hein 1993). Hein (1993) melanjutkan bahwa pada dasarnya pengungsi secara permanen tinggal di luar negeri dan tidak dapat kembali ke negara asal. Hal ini berbeda dari migran, yang dapat kembali secara leluasa ke negara asal. Hal ini juga berlaku bagi pengungsi Korea Utara di Korea Selatan.

World system theory menguraikan beberapa perbedaan antara migrasi dan pengungsi. Migrasi antarnegara core merepresentasikan percampuran aliran ekonomi dan politik, sedangkan migrasi dari negara periferi ke negara core meliputi migrasi dan pergerakan pengungsi. The UNHCR's Handbook and Guidelines, dalam penjelasan mengenai prosedur dan kriteria penetapan status pengungsi, mendefinisikan migran ekonomi sebagai seseorang yang melakukan perpindahan karena pertimbangan ekonomi. Migran ekonomi memilih untuk berpindah untuk memperbaiki prospek masa depan, sedangkan pengungsi terpaksa berpindah untuk menyelamatkan kehidupan atau melindungi kebebasan mereka (Cho 2013). Sebagai orang-orang yang meninggalkan negara asal karena berbagai faktor politik dan ekonomi domestik serta membutuhkan perlindungan dan bantuan internasional, pengungsi menjadi sebuah permasalahan kemanusiaan (Choi 2018).

\section{Penyebab Terjadinya Gelombang Pengungsi Korea Utara dan Permasalahan Integrasi}

Pelanggaran hak asasi manusia oleh pemerintah Korea Utara merupakan isu besar yang menjadi alasan bagi pengungsi untuk melakukan penyebrangan (Haggard dan Noland 2006). Permasalahan-permasalahan yang terjadi pada pengungsi Korea Utara tidak hanya bersifat kemanusiaan, namun juga politis dalam hal perpindahan manusia. Apabila ditelusuri ke belakang, Perang Korea yang berakhir pada 1953 telah membagi teritori kedua negara melalui garis paralel ke-38. Hal ini kemudian menyebabkan masyarakat kedua negara tidak dapat kembali ke kampung halaman, sehingga terpisah dari keluarganya. Permasalahan ini menjadi salah satu faktor pendorong yang disebabkan oleh adanya agenda politik. Dorongan untuk kembali berkumpul bersama keluarga yang terpisah oleh garis paralel ke-38, dengan demikian, menjadi salah 
satu motivasi yang kuat. Selain pengungsi, istilah yang seringkali digunakan oleh Korea Selatan terhadap pengungsi Korea Utara adalah penyeberang atau defectors.

Sejak berakhirnya Perang Dingin, peningkatan jumlah pengungsi Korea Utara terjadi sebagai akibat dari kegagalan Korea Utara untuk melindungi warga negaranya dan menanggapi krisis politik dan ekonomi yang terjadi (Choi 2018). Lankov (2006) kemudian menambahkan bahwa Sunshine Policy yang dicanangkan oleh Kim Dae Jung juga menjadi salah satu faktor utama bagi peningkatan jumlah pengungsi Korea Utara di Korea Selatan. Sunshine Policy mendukung berbagai upaya unifikasi kedua Korea, salah satunya adalah mempertemukan keluarga yang terpisah serta sedikit banyak membuka pintu Korea Utara untuk berbagai kerja sama dengan Korea Selatan.Oleh karena itu, keinginan warga Korea Utara untuk memulai kehidupan baru di Korea Selatan meningkat mulai awal dekade 2000-an, seperti yang tertera pada Tabel 1.

Negara-negara memainkan peran kunci dalam menentukan siapa yang menjadi pengungsi dan tanggung jawab serta kewajiban institusional apa yang harus dijalankan negara bagi orang-orang Korea Utara yang terlantar. Choi (2018) mengatakan bahwa ketika para pengungsi Korea Utara datang ke Korea Selatan, mereka menjalani prosedur di pusat perlindungan. Dalam prosedur ini, lembaga pemerintah, termasuk Badan Intelijen Nasional (NIS), melakukan interogasi dengan menanyai para pengungsi tersebut tentang motivasi mereka untuk pergi, beserta aspek-aspek lain dari latar belakang mereka. Telah dijelaskan sebelumnya bahwa penerimaan pengungsi Korea Utara telah menjadi agenda politik sejak pemerintahan Park Chung Hee dan terus berlanjut hingga saat ini, yang dibuktikan pemerintah melalui Kementerian Unifikasi dengan penyediaan fasilitas Hanawon. Dengan demikian, setidaknya pengungsi memiliki gambaran besar untuk kehidupannya saat pertama kali datang di Korea Selatan.

Sebenarnya terdapat dua negara dengan potensi untuk menjadi tujuan pengungsi Korea Utara, yaitu Cina dan Korea Selatan. Namun, Cina bukan merupakan negara tujuan yang tepat karena Cina memiliki kesepakatan dengan Korea Utara untuk menerapkan "kebijakan repatriarsi paksa" (Cohen 2014). Cina telah mulai secara aktif melacak pengungsi Korea Utara karena tekanan dari pemerintah Korea Utara (Lee et al. 2001). Bagi pengungsi Korea Utara, dapat dikatakan bahwa memilih Cina sebagai negara destinasi sama dengan melakukan bunuh diri, karena Korea Utara memberikan 
hukuman yang berat terhadap pembelot yang melarikan diri. Sejak 1986, Cina dan Korea Utara telah bekerja sama dalam perjanjian bilateral Mutual Cooperation Protocol for the Work of Maintaining National Security and Social Order in the Border Areas (U.S. state Department 2005 dalam Kurlantzick dan Manson 2006). Cina juga mengklaim bahwa pemulangan paksa merupakan hal yang penting untuk menjaga keamanan nasional, ketertiban sosial dan kontrol perbatasan (Cohen 2014). Maka dari itu, Korea Selatan menjadi satusatunya tujuan yang dianggap ideal bagi pengungsi Korea Utara.

Park et al. (2018) melanjutkan bahwa 49,3 persen pengungsi dewasa Korea Utara telah mengalami dan menyaksikan peristiwa yang mengancam kehidupannya (life threatening event). 71 persen di antara pengungsi muda dari Korea Utara telah mengalami insiden traumatis (seperti pembunuhan anggota keluarganya). Sebagai akibat dari peristiwa-peristiwa traumatis semacam ini, pengungsi Korea Utara menjadi rentan secara mental. Sebagian besar pengungsi Korea Utara yang diwawancarai mengungkapkan bahwa mereka membelot karena ketakutan akan penganiayaan yang didasarkan pada perbedaan pendapat politik. Beberapa pengungsi bahkan mengungkapkan bahwa mereka dianiaya karena pembelotan yang dilakukan oleh keluarga mereka, mengekspresikan perbedaan pendapat politik, dan mendengarkan musik Korea Selatan (Cho 2013). Selain mengkhianati rahasia negara, akses terhadap radio asing atau televisi dapat dianggap sebagai tindakan pengkhianatan dan dapat dihukum mati (International Crisis Group 2011).

Pemilihan Korea Selatan sebagai negara destinasi didasari oleh adanya kesamaan persepsi sejarah. Selain itu, dengan adanya konflik di Semenanjung Korea, Selatan dirasa lebih aman untuk pengungsi mencari suaka. Menurut Lee (2016) hukum di Korea Selatan memiliki keunikannya sendiri sebagai satu-satunya negara yang mewakili Semenanjung Korea. Lee (2016) melanjutkan bahwa dalam hukum Korea Selatan, orang dari Korea Utara secara teori tidak dapat mengambil kewarganegaraan Korea Utara, dan sebaliknya harus mengambil kewarganegaraan Korea Selatan karena berada di bawah yuridiksi Korea Selatan. Maka dari itu, Korea Selatan menjadi negara yang paling aman bagi pengungsi Korea Utara. Keinginan untuk kehidupan yang lebih baik juga merupakan salah satu alasan bagi pengungsi Korea Utara untuk meninggalkan negara mereka. Di bawah pemerintahan komunis yang terpusat, masyarakat tidak memiliki kebebasan politik, ekonomi, bahkan hak asasi manusia sebagai individu. 
Choi (2018) mengatakan bahwa pemerintah memainkan peran kunci dalam memberikan perlindungan, status hukum, bantuan, dan pendidikan sosial. Meninggalkan tanah air karena takut akan penganiayaan, permasalahan lingkungan, ekonomi, atau politik lainnya merupakan masalah dalam domain hak individu sebagai manusia. Melihat kembali pada pendekatan konseptual world system theory, kontras ideologi antara Korea Utara dan Korea Selatan sering kali menjadi faktor pendorong dan penarik untuk melakukan migrasi. Hal ini dikarenakan perekonomian di Korea Selatan sangat kontras dengan perekonomian Korea Utara. Pengungsi dari Korea Utara menganggap bahwa Korea Selatan menyediakan harapan untuk kehidupan yang baru.

\section{Integrasi dan Permasalahan Sosial}

Jumlah orang Korea Utara yang memasuki Korea Selatan setiap tahun sejak 2006 telah mencapai lebih dari 2.000 (Song 2013). KINU (Korea Institute for National Unification) menjadi lembaga pemerintahan yang menangani langsung pengungsi Korea Utara di Korea Selatan. Pemerintah Korea Selatan menyediakan program dukungan penyesuaian bagi pengungsi Korea Utara, terutama melalui berbagai program pelatihan dan pendidikan (misalnya melalui program-program pendidikan untuk meningkatkan pemahaman pengungsi tentang perbedaan budaya, politik, dan sistem ekonomi antara Korea Utara dan Korea Selatan) (Kim 2012). Melalui hanawon, pengungsi Korea Utara mendapat berbagai pelatihan soft skill untuk membekali mereka tentang budaya yang berkembang di masyarakat Korea Selatan. Kim (2012) mengatakan bahwa fasilitas program pelatihan yang diberikan pada pengungsi setidaknya berfokus pada dua hal, yaitu pemulihan kesehatan-baik mental maupun fisik-dan pemahaman tentang masyarakat Korea Selatan.

Pada tahun 2005, Kementerian Unifikasi Korea Selatan mencatat bahwa ketidakmampuan pengungsi Korea Utara dalam aspek bahasa menjadi hambatan utama dalam penerimaan mereka ke dalam lapangan pekerjaan, dibanding dengan kapabilitas mereka dalam melakukan pekerjaan (Kim dan Jang 2007). Seiring perkembangan zaman, pengungsi Korea Utara ke Korea Selata tidak lagi terbatas pada anggota masyarakat Korea Utara yang "istimewa", tetapi juga petani miskin atau pekerja (Eschborn 2014). Tidak hanya sampai di situ, pengungsi Korea Utara masih harus beradaptasi dengan budaya lokal. Walaupun keduanya memiliki latar belakang budaya yang sama, nyatanya masyarakat kedua Korea telah mengalami 
perkembangan kebudayaan yang berbeda. Tekanan dan trauma berat yang banyak dibahas oleh para pengungsi meliputi stres akulturasi, tekanan hidup di tempat di mana dialek dan budaya yang dominan berbeda, penolakan identitas diri, daya saing masyarakat baru, dan kesulitan dalam memercayai dan memahami orang Korea Selatan (Kim dan Lee 2009).

Permasalahan integrasi dan sosial selanjutnya adalah mengenai bagaimana kehidupan pengungsi Korea Utara di Korea Selatan setelah menetap. International Crisis Group (2011) menjelaskan bahwa terdapat permasalahan-permasalahan yang dihadapi oleh pengungsi Korea Utara dalam proses integrasi. Permasalahan yang pertama adalah kesehatan, baik mental maupun fisik. Selain permasalahan mental yang membatasi kehidupan baru mereka, seperti PTSD yang telah disebutkan, kebanyakan pengungsi Korea Utara juga mengalami malnutrisi. Merespon ini, pemerintah Korea Selatan melalui Hanawon Settlement Centre memberikan fasilitas untuk permasalahan kesehatan pengungsi Korea Utara, dan setelah tiga bulan pengungsi dapat dilepaskan ke masyarakat. Bukan tanpa celah, hal ini kemudian menjadikan pengungsi bergantung pada bantuan dari pemerintah dengan tanpa memiliki pekerjaan, atau pekerjaan yang bergaji rendah.

Permasalahan-permasalahan mengenaimata pencaharian pengungsi Korea Utara di Korea Selatan meliputi pengangguran, hambatan budaya, dan permasalahan hutang dan keuangan. International Crisis Group (2011) menjelaskan lebih lanjut bahwa hanya terdapat 439 (4\%) dari pengungsi Korea Utara yang memeroleh pekerjaanpekerjaan berkeahlian tinggi (skilled jobs), dan 381 pengungsi bekerja di bidang administrasi. Dari sisi penyedia kerja pun, permasalahan bahasa dan kurangnya pengetahuan mengenai nilai dan norma yang berkembang di masyarakat menjadi hambatan bagi penyedia kerja untuk memberikan pekerjaan pada pengungsi. Hambatan budaya juga menjadi salah satu penghambat, karena kebiasaan para pengungsi untuk mengikuti segala sesuatu yang diputuskan oleh pemerintah menjadikan sulit bagi mereka untuk melakukan segala sesuatu secara bebas di Korea Selatan, termasuk dalam hal mencari nafkah. Hal yang menjadi menarik adalah bahwa ideologi Korea Utara masih kental dalam pola pikir mereka, sehingga mereka menganggap bahwa uang merupakan instrumen perbudakan kapitalisme. Sebagai akibat dari ini, mereka merasa tidak ingin "diperbudak" untuk mendapatkan uang, tetapi pada saat yang bersamaan juga putus asa untuk mendapatkan uang. 
Terdapat pendapat bahwa permasalahan adaptasi dan penyesuaian pada pengungsi akan benar-benar berhasil ketika unifikasi terwujud. Tanpa unifikasi, proses penyesuaian dan adaptasi sangat sulit dilakukan. Menurut studi Dr Jeon Woo-taek dari Yonsei University Medical School dalam International Crisis Group (2011), hampir 80\% dari pengungsi yang telah disurvei memiliki perasaan ambivalen terhadap uang. Hal selanjutnya yang menjadi permasalahan bagi para pengungsi adalah hutang, karena saat melintasi perbatasan, para pengungsi dibantu oleh broker dengan bayaran besar. Tidak jarang, pengungsi Korea Utara bersedia melakukan pekerjaan apapun untuk melunasi biaya broker ini, bahkan banyak wanita di antara mereka terpaksa bekerja dalam industri seks. Kurangnya kemampuan dan keterampilan pengungsi Korea Utara menjadi faktor utama dari kesulitan mereka dalam mendapat perkerjaan yang layak dan bersaing dengan masyarakat Korea Selatan pada umumnya. Mengutip Lee (2013) yang melakukan wawancara kepada salah seorang pengungsi yang mengeluhkan kekhawatirnya akan kurangnya keterampilan untuk bekerja:

"I began to work with enthusiasm and strong determination, but soon I found that my skills were lacking. I also felt fear when I observed South Koreans working hard. I was greatly shocked and felt anxious." (Lee 2013).

Permasalahan sosial yang terakhir adalah diskriminasi yang dihadapi pengungsi di Korea Selatan. Merujuk kembali pada pendekatan konseptual diatas, masyarakat Korea Selatan yang multikultur tidak secara otomatis menjadikan mereka berpandangan multikulturalis. Salah satu bentuk diskriminasi dari masyarakat Korea Selatan ditujukan terhadap perbedaan logat atau dialek (satori) dalam bahasa Korea yang digunakan oleh pengungsi Korea Utara. International Crisis Group (2011) menjelaskan lebih lanjut bahwa para pengungsi Korea Utara lebih cenderung sakit dan lebih miskin ketimbang saudara-saudara mereka di Selatan, sebagai konsekuensi dari sejarah gizi dan perawatan medis yang jauh lebih buruk. Dalam aspek bahasa dan sosial, mereka memiliki aksen yang khas, menggunakan kata-kata yang berbeda, dan kurang berpengalaman dalam menghadapi tuntutan kehidupan sehari-hari dalam masyarakat yang maju dan terbuka. Sebagai konsekuensi dari ini, kebanyakan pengungsi Korea Utara telah mengalami isolasi dan marjinalisasi oleh masyarakat Korea Selatan (Lee 2003 dan Yun 2006 dalam Lee 2013). 
Diskriminasi serius yang seringkali diperoleh pengungsi Korea Utara dari masyarakat Korea Selatan kemudian berdampak buruk terhadap kehidupan psikososial mereka. Terlebih lagi, mereka masih harus mempelajari dialek Korea Selatan yang banyak terpengaruh globalisasi sehingga memiliki banyak kata serapan asing. Permasalahan bahasa ini yang kemudian dianggap menghambat proses integrasi pengungsi Korea Utara ke dalam masyarakat Korea Selatan. Meskipun keduanya seolah-olah berbicara dalam bahasa yang sama, ekspresi standar Korea Selatan mengandung sejumlah besar kata-kata dan idiom yang asing bagi pengungsi Korea Utara (Jeon 1992 dalam Lee 2013). Namun, seiring berjalannya waktu, kesadaran masyarakat Korea Selatan mulai membaik dan terbuka terhadap permasalahan perbedaan identitas dengan pengungsi Korea Utara. Bukan tanpa keluhan, pengungsi Korea Utara seringkali mengungkapkan keluhan karena merasa dianggap sebagai penduduk kelas dua, yang mengalami diskriminasi alih-alih simpati. Tidak hanya itu, para pengungsi sering kali bertanya-tanya apakah kehidupan baru di Korea Selatan yang penuh dengan tantangan sebanding dengan perjuangan mereka dalam melintasi perbatasan. Mengutip Cho Young Gwan (dalam Lankov 2006), "Pertanyaannya adalah bahwa para pengungsi (melewati garis kematian perbatasan Korea Utara) datang ke Korea Selatan yang mereka pandang sebagai tanah perjanjian, tetapi harapan mereka tidak terpenuhi di sini," (Lankov, 2006).

\section{Kesimpulan}

Pengungsi Korea Utara memiliki latar belakang yang penuh persekusi dan kekerasan politik dari pemerintah negaranya sendiri. Mereka melarikan diri dengan harapan untuk mendapatkan kehidupan yang lebih baik. Perlakuan Korea Utara yang dianggap kejam terhadap masyarakatnya, ditambah dengan tidak adanya prospek perekonomian yang lebih baik, menjadi faktor pendorong dalam gelombang pengungsi Korea Utara ke Korea Selatan. Mengingat Korea Selatan memiliki ideologi yang berbeda kontras, pengungsi Korea Utara memandang Korea Selatan sebagai ladang hijau untuk harapan hidup yang baru. Telah dijelaskan bahwa negara dengan ekonomi kapitalis dapat menjadi faktor penarik bagi pengungsi yang mencari suaka. Namun, dengan berpindahnya pengungsi Korea Utara ke Korea Selatan tidak lantas berjalan dengan lancar seperti yang mereka harapkan. Permasalahan sosial yang timbul dan berbagai perbedaan dengan masyarakat Korea Selatan dapat menghambat proses integrasi itu sendiri. 
Salah satu perbedaan signifikan antara kedua kelompok masyarakat tersebut terletak pada kebiasaan hidup. Masyarakat Korea Utara terbiasa untuk dikendalikan sepenuhnya oleh pemerintah secara terpusat dan tidak diberi ruang untuk pengambilan keputusan secara mandiri. Dengan kata lain, masyarakat Korea Utara tidak familiar dengan hak asasi manusia. Kontras sebaliknya, kehidupan di Korea Selatan membebaskan masyarakatnya untuk bergerak secara leluasa. Perbedaan ini menyebabkan pengungsi Korea Utara tidak terbiasa dengan pola hidup di Korea Selatan. Selain itu, permasalahan-permasalahan sosial seperti pengangguran, isu kesehatan baik mental maupun fisik, hutang, perbedaan budaya, hingga diskriminasi menjadi tantangan tersendiri bagi pengungsi Korea Utara untuk berintegrasi dan memulai kehidupan barunya di Selatan. 


\section{Daftar Pustaka}

\section{Buku atau Bagian dalam Buku}

Haggard, Stephan, dan Marcus Noland, 2006. "The North Korean Refugees as a Human Rights Issue" dalam Stephan Haggard and Marcus Noland (eds.). The North Korean Refugee Crisis: Human Rights and International Responses. Washington D.C.: U.S. Committee for Human Rights in North Korea.

Kymlicka, Will, 2012. Multiculturalism: Success, Failure, and the Future. Washington D.C.: Migration Policy Institute.

Kurlantzick, Joshua, dan Jana Manson, 2006. "North Korea Refugees: The Chinese Dimension", dalam Stephan Haggard and Marcus Noland (eds.). The North Korean Refugee Crisis: Human Rights and International Responses. Washington, D.C.: U.S. Committee for Human Rights in North Korea.

\section{Artikel Jurnal}

Ahn, Ji-Hyun, 2013. "Global migration and the racial project in transition: institutionalizing racial difference through the discourse of multiculturalism in South Korea", Journal of Multicultural Discourses, 8 (1): 29-47.

Cho, Jeanyoung Jeannie, 2013. "Systemizing the Fate of the Stateless North Korean Migrant: A Legal Guide to Preventing the Automatic Repatriation of North Korean Migrants in China”, Fordham International Law Journal, 37 (1): 175234 .

Choi, Gyubin, 2018. "North Korean Refugees in South Korea: Change and Challenge in Settlement Support Policy", The Korean Journal of International Studies, 16 (1): 77-98.

Cohen, Roberta, 2014. “China's Forced Repatriation of North Korean Refugees Incurs United Nations Censure”, International Journal of Korean Studies, 18 (1): 59-89.

Hein, Jeremy, 1993. "Refugee, Immigrant, and The State", Annual Review of Sociology, 19: 43-59.

Kim, Hyun Kyoung, dan Ok Ja Lee, 2009. “A Phenomenological 
Study on the Experience of North Korean Refugees", Nursing Science Quarterly, 22 (1): 85-88.

Kim, Jih Un, dan Dong-Jin Jang, 2007. "Aliens among Brothers? The Status and Perception of North Korean Refugees in South Korea”, Asian Perspective, 31 (2): 5-22.

Kim, Sung Kyung, 2012. “'Defector,' 'Refugee,' or 'Migrant'? North Korean Settlers in South Korea's Changing Social Discourse", North Korean Review, 8 (2): 94-110.

Lankov, Andrei, 2006. "Bitter Taste of Paradise: North Korean Refugees in South Korea”, Journal of East Asian Studies, 6: 105-37.

Lee, Dong Bae, 2013. "The Influence of North Korean Political Ideologies on The Integration of North Korean Defectors in South Korea", Studia Orientalia Electronica, 1: 1-20.

Lee, Whiejin, 2016. "The Status of North Korean Refugee and Their Protection in International Law". The Journal of East Asian Affairs, 30 (2): 43-82.

Lee, Yunhwan et al., 2001. "Trauma Experience of North Korean Refugees in China", American Journal of Preventive Medicine, 20 (3): 225-9.

Park, Subin, Yeeun Lee, dan Jin Yong Jun, 2018. "Trauma and Depression among North Korean Refugees: The Mediating Effect of Negative Cognition”, International Journal of Environmental Research and Public Health, 15 (4): 591.

Song, Jinyoung, 2013. “'Smuggled Refugees': The Social Construction of North Korean Migration”, International Migration, 51 (4): 158-173.

Watson, Iain, 2010. "Multiculturalism in South Korea: A Critical Assessment”, Journal of Contemporary Asia, 40 (2): 337346.

Watson, Iain, 2012. "Paradoxical Multiculturalism in South Korea", Asian Politics \& Policy, 4 (2): 233-258. 


\section{Laporan Penelitian}

Eschborn, Nobert, 2014. "North Korean Refugees in South Korea: Arduous Escape and Difficult Integration", ISPSW Strategy Series Issue No. 292. Berlin: Institute for Strategic, Political, Security and Economic Consultancy.

International Crisis Group, 2011. "Strangers at Home: North Koreans in the South”, Asia Report No. 208. Brussels: International Crisis Group.

\section{Makalah Konferensi}

Han, Gil-Soo, 2012. "Othering North Korean Refugees in South Korea: A Literature Review and the Concept of NouveauRiche Nationalism", dalam Australian Sociological Association Annual Conference 2012: Emerging and Enduring Inequalities, 26-29 November. Brisbane: Australian Sociological Association. 